\title{
Antiglobulins and Glomerulonephritis
}

\author{
CLASSIFICATION OF PATIENTS BY THE REACTIVITY \\ OF THEIR SERA AND RENAL TISSUE \\ WITH AGGREGATED AND NATIVE HUMAN IgG
}

\author{
Roger D. Rossen, Margaret A. Reisberg, John T. Sharp, Wadi N. Suki, \\ Francis X. Schloeder, Leighton L. Hill, and Garabed Eknoyan \\ From the Departments of Microbiology and Immunology, Medicine, and \\ Pediatrics, Baylor College of Medicine, and the Laboratories of Immunology \\ Research, The Veterans and The Methodist Hospitals, Houston, Texas 77025
}

\begin{abstract}
A B S T R A C T Renal biopsies and sera from 41 consecutive patients were studied to determine if antiglobulins were found more frequently in patients with severely diseased glomeruli. Patients were classified into three groups: A, 12 patients with normal renal function and minimal histological evidence of glomerular disease; $\mathrm{B}$, 18 patients with normal renal function but distinctly abnormal biopsies (16 cases) or proteinuria $>16 \mathrm{~g} / 24 \mathrm{~h}$ ( 2 cases) ; and C, 11 patients with both decreased function and abnormal histology. Positive latex fixation tests for rheumatoid factor were found in none of group A, four (22\%) of group B, and five (45\%) of group C patients. Sera heated $56^{\circ} \mathrm{C}$ for 30 min contained precipitins reactive with heat-aggregated $\mathrm{IgG}$ in none of seven group A, five of ten (50\%) group B, and four of ten $(40 \%)$ group $\mathrm{C}$ patients. The quantity of ${ }^{125} \mathrm{I}$-labeled patient globulin which bound to immunoadsorbents coated with Cohn fraction II in competition with an equal quantity of ${ }^{131}$ I-labeled globulin from pooled plasma of normal donors was also measured. Patient globulins bound in significantly greater quantity $(\geq 2 \mathrm{SD})$ than the control in none of the group A, 7 of $18(39 \%)$ group B, and 7 of $11(64 \%)$ group $C$ patients. Renal biopsies from 18 patients were also studied for the ability to fix fluorescein-conjugated heat-aggregated and native human $\mathrm{IgG}$. None of nine tissue specimens from group A or B patients fixed either fluorescein-conjugated protein whereas tissue from eight of nine group C patients showed glomerular localization of one or both reagents. Severity of disease as judged by renal
\end{abstract}

Received for publication 21 February 1974 and in revised form 9 April 1975. function and glomerular histology correlated with the presence of tissue-fixed and serum antiglobulins. Thus, detection of antiglobulins in glomeruli and sera of patients with glomerulonephritis may indicate a relatively poor prognosis and raises the possibility that antiglobulins may be implicated in some way in the pathophysiology of human glomerulonephritis.

\section{INTRODUCTION}

Experience with patients with chronic glomerulonephritis and with the experimental models which mimic the human disease has emphasized that there are many factors which influence the severity of the disease and the rate of progression to renal insufficiency (1-6). Yet at the onset of disease in many cases it is still difficult to identify those in whom glomerular inflammation and scarring will remit or progress in an aggressive manner $(7-8)$.

In rheumatoid arthritis (RA), ${ }^{1}$ on the other hand, a disease in which antigen-antibody complexes also provoke inflammation and contribute to tissue injury, the prognosis to some extent correlates with the level of rheumatoid factors. Indeed, the inflammatory response evoked by antigen-antibody complexes in the synovia may be increased by antiglobulin present in the tissue (9-12). Similarly in some patients with systemic lupus erythematosus (SLE) and glomerulonephritis, cryoglobulins with antiglobulin activity may be found in

${ }^{1}$ Abbreviations used in this paper: $\mathrm{C}_{\mathrm{c}_{r}}$, creatinine clearance; $\mathrm{Cr}$, creatinine; FII, Cohn fraction II; PBS, $0.15 \mathrm{M}$ $\mathrm{NaCl}$ buffered at $\mathrm{pH} 7.4$ with $0.01 \mathrm{M}$ phosphate; RA, rheumatoid arthritis; SLE, systemic lupus erythematosus. 
TABLE I

Renal_Histology and Clinical Summary

\begin{tabular}{|c|c|c|c|c|c|c|c|c|}
\hline \multirow{3}{*}{$\begin{array}{l}\text { Patient } \\
\text { no. }\end{array}$} & \multirow[b]{3}{*}{ Age } & \multirow[b]{3}{*}{ Sex } & \multirow{3}{*}{$\begin{array}{l}\text { Duration } \\
\text { of } \\
\text { illness }\end{array}$} & \multicolumn{4}{|c|}{ Histology of renal biopsy } & \multirow[b]{3}{*}{ Clinical comments } \\
\hline & & & & \multirow[b]{2}{*}{ Light and electron microscopy } & \multicolumn{3}{|c|}{ Immunofluorescence } & \\
\hline & & & & & A & G & $\mathbf{M}$ & \\
\hline & $y r$ & & mo & & & & & \\
\hline \multicolumn{9}{|c|}{ al by light microscopy; normal renal function } \\
\hline 40 & 34 & $\mathbf{M}$ & 48 & WNL & 0 & $2+$ & $1+I$ & SLE \\
\hline 38 & 4 & $\mathrm{~F}$ & 10 & WNL (including EM) & \multicolumn{3}{|c|}{ No glomeruli seen } & Persistent microscopic hematuria \\
\hline 37 & 41 & $\mathrm{~F}$ & 4 & WNL (? $\uparrow$ in cellularity) & $1+I$ & $1+I$ & $3+I$ & SLE \\
\hline 35 & 18 & $\mathbf{M}$ & 1 & WNL & ND & $1+L$ & $3+I$ & Spontaneous gross hematuria, ASO $=125$ \\
\hline 34 & 15 & $\mathbf{M}$ & 1 & WNL; rarely, periglomerular fibrosis & 0 & $1+I$ & $2+I$ & $\begin{array}{l}\text { Microhematuria found on routine } \\
\text { examination }\end{array}$ \\
\hline 33 & 4 & $\mathbf{F}$ & 4 & WNL (EM shows foot process fusion) & $1+I$ & $2+\mathrm{I}$ & $2+I$ & Acute GN with nephrotic syndrome \\
\hline 31 & 17 & $\mathbf{F}$ & 12 & $\begin{array}{l}\text { WNL (EM shows BM thickening } \\
\text { and dense material in mesangium) }\end{array}$ & $2+\mathrm{L}$ & $3+I$ & $1+I$ & SLE \\
\hline 30 & 41 & $\mathbf{F}$ & 51 & WNL & 0 & $1+\mathrm{L}$ & $2+I$ & SLE \\
\hline 24 & 4 & $\mathbf{M}$ & 2 & WNL (EM shows foot process fusion) & \multicolumn{3}{|c|}{ No glomeruli seen } & Idiopathic nephrotic syndrome \\
\hline 23 & 14 & $\mathbf{M}$ & 30 & WNL (including EM) & $1+\mathrm{L}$ & $3+L$ & $1+\mathrm{I}$ & Recurrent spontaneous gross hematuria \\
\hline 21 & 30 & $\mathrm{~F}$ & 17 & WNL & 0 & $3+\mathrm{L}$ & $1+I$ & Poststreptococcal GN \\
\hline 19 & 6 & $\mathbf{M}$ & $3 \frac{1}{2}$ & WNL (EM shows foot process fusion) & $3+I$ & $3+\mathrm{I}$ & $3+I$ & Idiopathic nephrotic syndrome \\
\hline \multicolumn{9}{|c|}{ Group B Renal biopsy abnormal or proteinuria $>2 \mathrm{~g} / 24 \mathrm{~h}$} \\
\hline 39 & 20 & $\mathbf{F}$ & 14 & Focal membranous GN & $1+I$ & $1+I$ & $3+I$ & SLE \\
\hline 36 & 21 & $\mathbf{F}$ & 24 & $\begin{array}{l}\text { Diffuse mesangial hypercellularity, } \\
\text { small subepithelial and mesangial } \\
\text { deposits, focal loop necrosis }\end{array}$ & $3+I$ & $3+I$ & $3+I$ & SLE \\
\hline 32 & 14 & $\mathrm{~F}$ & 32 & Membranoproliferative GN & $2+I$ & $2+I$ & $2+I$ & SLE \\
\hline 28 & 27 & $\mathrm{~F}$ & 2 & Focal membranous GN & 0 & $1+I$ & $1+I$ & $\begin{array}{l}\text { Nephrotic syndrome following an } \\
\text { influenza-like illness, ASO }=50\end{array}$ \\
\hline 27 & 31 & M & 5 & Focal proliferative GN & $2+\mathrm{L}$ & $2+\mathrm{L}$ & $2+L$ & Fever $100-101^{\circ} \mathrm{F}$ and microhematuria \\
\hline 26 & 18 & $\mathrm{~F}$ & 5 & Focal proliferative GN & $1+\mathrm{L}$ & $2+I$ & $2+\mathrm{L}$ & $\begin{array}{l}\text { Polyarthritis, negative SLE test, } \\
\text { microhematuria }\end{array}$ \\
\hline 25 & 39 & $\mathrm{~F}$ & 60 & Focal proliferative GN & 0 & $2+I$ & $2+I$ & SLE \\
\hline 22 & 25 & $\mathrm{~F}$ & 18 & Focal membranous GN & 0 & $2+\mathrm{L}$ & $1+\mathrm{I}$ & SLE \\
\hline 18 & 24 & $\mathbf{F}$ & 5 & Focal proliferative GN & 0 & $2+L$ & $1+I$ & $\begin{array}{l}\text { Microhematuria }+\mathrm{RBC} \text { casts noted on } \\
\text { routine exam }\end{array}$ \\
\hline 17 & 46 & $\mathbf{M}$ & 40 & Membranous GN & 0 & $3+I$ & 0 & Nephrotic syndrome \\
\hline 16 & 17 & $\mathbf{M}$ & 4 & Membranoproliferative GN & 0 & $2+I$ & $2+I$ & Poststreptococcal nephritis, ASO $=333$ \\
\hline 14 & 62 & $\mathbf{M}$ & 1 & WNL & $1+I$ & $2+\mathrm{L}$ & $2+I$ & $\begin{array}{l}\text { Nephrotic syndrome } 2 \text { yr after surgery } \\
\text { for carcinoma of colon }\end{array}$ \\
\hline 13 & 30 & $\mathbf{M}$ & 120 & Focal membranous GN & 0 & $1+\mathrm{I}$ & 0 & ?Hereditary nephritis \\
\hline 12 & 30 & $\mathbf{M}$ & 2 & $\begin{array}{l}\text { Rare periglomerular fibrosis; } \\
\quad 1 \text { of } 18 \text { glomeruli hyalinized }\end{array}$ & 0 & 0 & $2+I$ & Microhematuria \\
\hline 11 & 36 & $\mathbf{M}$ & 24 & Focal membranous GN & 0 & 0 & $1+I$ & ?Hereditary nephritis \\
\hline 8 & 66 & $\mathrm{~F}$ & 24 & $\begin{array}{l}\text { One of three glomeruli are sclerotic; } \\
\text { glomeruli are Congo red negative }\end{array}$ & 0 & $3+\mathrm{I}$ & $3+I$ & $\begin{array}{l}\text { Primary amyloidosis suggested by } \\
\text { biopsy of artery }\end{array}$ \\
\hline 7 & 56 & $\mathbf{M}$ & 1 & WNL & $1+\mathrm{L}$ & $3+\mathrm{L}$ & $2+L$ & $\begin{array}{l}\text { Raynaud's phenomenon, nephrotic } \\
\text { syndrome }\end{array}$ \\
\hline 2 & 53 & $\mathbf{M}$ & 7 & Membranoproliferative GN & 0 & $2+I$ & 0 & Steroid-resistant nephrotic syndrome \\
\hline \multicolumn{9}{|c|}{ Group C Diminished renal function $\left(\mathrm{Cr}>2.0 \mathrm{mg} / 100 \mathrm{ml}, \mathrm{C} C r \leqslant 60 \mathrm{ml} / \mathrm{min}\right.$ per $\left.1.73 \mathrm{~m}^{2}\right)$} \\
\hline 41 & 26 & $\mathbf{F}$ & 2 & $\begin{array}{l}\text { Diffuse membranoproliferative GN } \\
\text { with tuftal necrosis and crescents }\end{array}$ & $3+I$ & $3+I$ & $3+I$ & SLE \\
\hline 29 & 47 & $\mathbf{F}$ & 120 & End stage kidney & 0 & $2+I$ & $1+I$ & SLE \\
\hline 20 & 39 & $\mathbf{F}$ & 47 & $\begin{array}{l}\text { Membranoproliferative GN with } \\
\text { necrosis of tufts }\end{array}$ & $3+I$ & $3+I$ & $3+I$ & Nephrotic syndrome \\
\hline 15 & 12 & $\mathbf{F}$ & 7 & End stage kidney & 0 & 0 & $2+I$ & Malignant hypertension \\
\hline 10 & 26 & $\mathbf{F}$ & 45 & End stage kidney & 0 & $2+I$ & $3+\mathrm{I}$ & $\begin{array}{l}\text { Raynaud's phenomenon, malignant } \\
\text { hypertension }\end{array}$ \\
\hline 9 & 78 & $\mathbf{F}$ & 108 & Membranoproliferative GN & 0 & $1+I$ & $2+I$ & Sjögren's syndrome, SLE variant? \\
\hline 6 & 37 & $\mathbf{M}$ & 60 & Membranoproliferative GN & 0 & $1+I$ & 0 & SLE \\
\hline 5 & 44 & $\mathbf{M}$ & 7 & WNL & 0 & 0 & $1+\mathrm{L}$ & ?Polyarteritis \\
\hline 4 & 46 & $\mathbf{M}$ & 9 & Membranoproliferative GN & $1+\mathrm{L}$ & $1+L$ & $1+\mathrm{L}$ & Goodpasture's syndrome \\
\hline 3 & 20 & $\mathbf{M}$ & 3 & End stage kidney & $1+L$ & $2+I$ & $3+I$ & Rapidly progressive GN \\
\hline 1 & 34 & $\mathbf{F}$ & 24 & $\begin{array}{l}\text { Membranoproliferative GN with } \\
\text { focal necrosis and crescents }\end{array}$ & 0 & $3+1$ & $3+I$ & SLE \\
\hline
\end{tabular}

ASO, anti-streptolysin O titer; EM, electron microscopy; GN, glomerulonephritis; I, immune complex deposits; L, linear immunoglobulin deposits; RBC, red blood cell; WNL, within normal limits; $\uparrow$, increased. 
both the sera and the kidneys, suggesting that circulating antiglobulins can become entrapped amidst the immune complexes in the glomeruli. Conceivably, these cryoantiglobulins could likewise contribute to local inflammatory responses (13-15). Whether interactions of antiglobulins with circulating antigen-antibody complexes occur in patients with other types of glomerulonephritis either before or after the immune complexes impact on the glomerular membranes is not known $(14,15)$. Moreover, if they do, can such interactions affect glomerular inflammation? Antiglobulin-rich fractions from sera of patients with RA, which will not cause tissue injury when injected by themselves, can potentiate renal glomerular injury in experimental animals injected with nephrotoxic serum (16). It would seem, therefore, that antiglobulins in certain circumstances could also potentiate renal inflammation in human glomerulonephritis. If so, one would expect to see a relationship between the antiglobulin activity in sera and/or tissue and the severity of the renal lesions. Specifically, we have investigated whether the degree of renal glomerular injury as evaluated both histologically and by renal function tests at the time of renal biopsy correlates with the presence of factors which react with native or aggregated human IgG in serum or renal tissue.

\section{METHODS}

\section{Patient population}

41 consecutive patients whose diagnostic renal biopsies were submitted for histological examination were studied. Clinical records were reviewed to evaluate current and past levels of renal function and to search for clues to the etiology of the renal disease. On the basis of this clinical review and the histology of the renal biopsy without consideration of the results of immunofluorescence studies, patients were classified into three groups (Tables I and II).

Group $A$ (12 patients). Both serum creatinine ( $\mathrm{Cr}$ ) and/ or endogenous creatinine clearance $\left(\mathrm{C}_{\mathrm{Cr}_{r}}\right)$ corrected for body surface area were within normal limits; proteinuria was $<2.0 \mathrm{~g} / 24 \mathrm{~h}$; renal biopsy was within normal limits or showed only minimal abnormalities by light microscopy.

Group $B$ (18 patients). $\mathrm{Cr}$ and $\mathrm{C}_{\mathrm{Cr}}$ were within normal limits. The histology of the renal biopsy was abnormal by light microscopy in 16 cases. Two additional patients were included in this group despite a normal biopsy because proteinuria was $\geq 16 \mathrm{~g} / 24 \mathrm{~h}$.

Group $C$ (11 patients). The serum $\mathrm{Cr}$ was $22.0 \mathrm{mg} /$ $100 \mathrm{ml}$ or the $\mathrm{C}_{\mathrm{Cr}}$ was $\leq 60 \mathrm{ml} / \mathrm{min}$ per $1.73 \mathrm{~m}^{2}$. With the exception of one case with a serum $\mathrm{Cr}$ of $4.0 \mathrm{mg} / 100 \mathrm{ml}$ whose renal biopsy was read as normal (patient 5), the renal biopsy showed extensive histologic abnormalities in all cases.

A numerical rating was assigned to the renal histological picture as determined by light microscopy. Biopsies which appeared normal or showed equivocal abnormalities obtained a score of 1. Focal proliferative or focal membranous changes were given a score of 2 . Biopsies which showed all glomeruli involved with membranous or proliferative changes received a score of 3 . And biopsies which showed evidence of lobular necrosis, extensive scarring, or crescent formation were given a score of 4 . All biopsies were reviewed and classified by an independent pathologist.

A clinical score (severity index) for each patient which encompassed both renal functional abnormalities and the histologic picture of the renal biopsy was devised by adding the serum $\mathrm{Cr}$ and the numerical rating of the renal biopsy. Statistical comparisons relating antiglobulin levels to other factors were achieved by numerically ranking the various measurements from highest to lowest and comparing the ranks achieved by each patient for these measurements. Correlations between serological and clinical measurement were evaluated by chi-square analysis, the nonparametric Spearman rank correlation test, and the Kruskal-Wallis oneway analysis of variance (17).

\section{Histological studies of renal biopsies}

4- $\mu \mathrm{m}$ permanent sections, stained with hematoxylin and eosin and the periodic acid-Schiff reagent, were evaluated for an increase in glomerular cellularity, presence of inflammatory cells, fibrinoid, tuft necrosis, adhesions, and crescent formation. In some cases electron microscopic studies were also carried out.

Frozen tissue sections were evaluated by using fluoresceinconjugated reagents specific for human IgA, IgG, and IgM as previously described $(18,19)$. The intensity of fluorescence was graded on a 1 to $3+$ scale.

There was sufficient renal tissue in 18 cases to evaluate the ability of the glomerular deposits to bind native and aggregated human IgG $(20,21)$. Human $\operatorname{IgG}$ was extracted from Cohn fraction II (FII) (Pentex Research Products Div., Miles Laboratories Inc., Kankakee, Ill.) by DEAEcellulose chromatography and labeled at a 1:1 molar fluorescein-to-protein ratio (18). After rechromatography on DEAE-cellulose (22), aliquots were aggregated at $63^{\circ} \mathrm{C}$ for $20 \mathrm{~min}$. Tissue sections were incubated with aggregated IgG at a concentration of $1.5-2.0 \mathrm{mg} / \mathrm{ml}$ and with some of the same labeled IgG which had not been heated ("native" $\mathrm{IgG}$ ) at concentrations of $3.0 \mathrm{mg} / \mathrm{ml}$. Care was taken to test tissue sections promptly after removal from the cryostat without prior fixation.

In one case (patient 1) a surgical biopsy was available. Tissue sections from this patient were also tested with aggregated and native fluorescein-labeled human IgG which had been adsorbed with $0.5 \mathrm{mg}$ insolubilized human IgG per $\mathrm{mg}$ of fluorescein-conjugated protein. Blocking studies were carried out with unconjugated native and aggregated IgG used at the same protein concentration as the aggregated $\operatorname{IgG}$ conjugate and with unconjugated antibodies specific for human $\operatorname{IgG}, \operatorname{IgA}$, and $\operatorname{IgM}(18)$. Tissue sections which had been heated to $56^{\circ} \mathrm{C}$ for $30 \mathrm{~min}$ in a bath containing $0.15 \mathrm{M} \mathrm{NaCl}$, buffered at $\mathrm{pH} 7.4$ with $0.01 \mathrm{M}$ phosphate (PBS) before incubation with conjugates of aggregated and native human IgG were also studied.

\section{Serologic techniques}

Immunoadsorbent assay to measure reactivity of sera to insolubilized FII and other antigens. Patient sera were precipitated three times with $20.4 \%$ sodium sulfate. After dialysis, the sulfate-free globulins were labeled with ${ }^{125} \mathrm{I}$ by the iodine monochloride method (23). ${ }^{125}$ I-patient globulins were mixed with an equal weight of ${ }^{131}$ I-labeled globulin of approximately the same specific activity prepared from pooled plasma from healthy normal donors. The mixture of 
TABLE II

Comparison of Renal Function and Biopsy Scores with Tests for Serum Antiglobulin Activity and C3 Levels

\begin{tabular}{|c|c|c|c|c|c|c|c|c|c|c|c|}
\hline \multirow{2}{*}{$\begin{array}{c}\text { Patient } \\
\text { no. }\end{array}$} & \multirow[b]{2}{*}{$\mathrm{Cr}$} & \multirow[b]{2}{*}{$\mathrm{Ccr}_{\mathrm{r}}$} & \multirow[b]{2}{*}{ Proteinuria } & \multirow{2}{*}{$\begin{array}{l}\text { Kidney } \\
\text { histology } \\
\text { score* }\end{array}$} & \multicolumn{3}{|c|}{ FII-binding globulin } & \multirow{2}{*}{$\begin{array}{c}\text { Pptn } \\
\text { with } \\
\text { agg } \\
\text { IgG\& }\end{array}$} & \multirow{2}{*}{$\begin{array}{l}\text { Latex } \\
\text { fixation } \\
\text { titer }\end{array}$} & \multirow[b]{2}{*}{ C3\| } & \multirow{2}{*}{$\begin{array}{r}\text { Severity } \\
\text { index* }\end{array}$} \\
\hline & & & & & Patient & Control & Net $\ddagger$ & & & & \\
\hline & $\begin{array}{c}m g / 100 \\
m l\end{array}$ & $\begin{array}{c}m l / \min \\
\text { per } \\
1.73 \mathrm{~m}^{2}\end{array}$ & $g / 24 h$ & \multicolumn{4}{|c|}{$\mu g$ bound/mg added ( $\pm S D)$} & & & $m g / m l$ & \\
\hline
\end{tabular}

Group A Renal biopsy normal by light microscopy; normal renal function

\begin{tabular}{|c|c|c|c|c|c|c|c|c|c|c|c|}
\hline 40 & 1.1 & 86 & 0.4 & 1 & $39 \pm 7$ & $57 \pm 23$ & -18 & $\mathbf{0}$ & $\mathbf{0}$ & 0.77 & 2.1 \\
\hline 38 & 0.3 & ND & $\mathbf{0}$ & 1 & $59 \pm 5$ & $72 \pm 12$ & -13 & ND & $\mathbf{0}$ & 0.46 & 1.3 \\
\hline 37 & 0.7 & 119 & $\mathbf{0}$ & 1 & $49 \pm 12$ & $58 \pm 19$ & -9 & ND & 0 & 0.63 & 1.7 \\
\hline 35 & 1.1 & 98 & $\mathbf{0}$ & 1 & $67 \pm 5$ & $73 \pm 11$ & -6 & $\mathbf{0}$ & $\mathbf{0}$ & 0.74 & 2.1 \\
\hline 34 & 0.7 & ND & 0.3 & 1 & $53 \pm 14$ & $54 \pm 24$ & -1 & $\mathbf{0}$ & 0 & 1.40 & 1.7 \\
\hline 33 & 0.3 & ND & 0.5 & 1 & $66 \pm 6$ & $67 \pm 15$ & -1 & ND & 0 & 0.94 & 1.3 \\
\hline 31 & 1.0 & 85 & 1.2 & 1 & $37 \pm 8$ & $36 \pm 8$ & 1 & $\mathbf{0}$ & 0 & ND & 2.2 \\
\hline 30 & 0.7 & ND & $<0.1$ & 1 & $73 \pm 8$ & $69 \pm 10$ & 4 & 0 & 0 & 0.88 & 1.7 \\
\hline 24 & 0.8 & ND & $>200 \mathrm{mg} / 100 \mathrm{ml}$ & 1 & $78 \pm 3$ & $71 \pm 11$ & 7 & ND & 0 & 1.15 & 1.8 \\
\hline 23 & 1.0 & 65 & $<0.1$ & 1 & $77 \pm 13$ & $69 \pm 10$ & 8 & ND & 0 & 0.94 & 2.0 \\
\hline 21 & 0.9 & 116 & 0.2 & 1 & $64 \pm 22$ & $51 \pm 20$ & 13 & $\mathbf{0}$ & 0 & 0.94 & 1.9 \\
\hline 19 & 0.9 & ND & 0.2 & 1 & $84 \pm 9$ & $71 \pm 11$ & 13 & 0 & 0 & 1.65 & 1.9 \\
\hline
\end{tabular}

Group B Renal biopsy abnormal or proteinuria $>2 \mathrm{~g} / 24 \mathrm{~h}$

\begin{tabular}{|c|c|c|c|c|c|c|c|c|c|c|c|}
\hline 39 & 0.7 & 109 & 3.3 & 2 & $40 \pm 9$ & $57 \pm 20$ & -17 & ND & $1: 320$ & 0.55 & 2.7 \\
\hline 36 & 1.3 & 62 & 1.1 & 3 & $64 \pm 2$ & $72 \pm 10$ & -8 & + & 0 & 0.78 & 4.3 \\
\hline 32 & 1.2 & 81 & 1.4 & 3 & $73 \pm 4$ & $73 \pm 10$ & 0 & ND & 0 & 0.62 & 4.2 \\
\hline 28 & 1.0 & 69 & 15.0 & 2 & $78 \pm 6$ & $73 \pm 10$ & 5 & 0 & $\mathbf{0}$ & 1.00 & 3.0 \\
\hline 27 & 0.9 & 131 & 0 & 2 & $41 \pm 7$ & $36 \pm 7$ & 5 & ND & 0 & ND & 2.9 \\
\hline 26 & 1.1 & 71 & 0.9 & 2 & $42 \pm 8$ & $35 \pm 8$ & 7 & $\mathbf{0}$ & 0 & 1.52 & 3.1 \\
\hline 25 & 0.9 & 81 & $<0.1$ & 2 & $79 \pm 7$ & $72 \pm 11$ & 7 & ND & 0 & 1.00 & 2.9 \\
\hline 22 & 0.9 & 106 & 1.0 & 2 & $45 \pm 13$ & $33 \pm 8$ & 12 & ND & 0 & ND & 2.9 \\
\hline 18 & 0.8 & 130 & $<0.1$ & 2 & $71 \pm 28$ & $54 \pm 21$ & 17 & 0 & $1: 160$ & 0.93 & 2.8 \\
\hline 17 & 1.0 & 110 & 0.6 & 3 & $76 \pm 21$ & $58 \pm 18$ & 18 & + & $1: 10,240$ & 0.75 & 4.0 \\
\hline 16 & 1.1 & 138 & 2.9 & 3 & $78 \pm 24$ & $55 \pm 16$ & 23 & ND & 0 & 0.83 & 4.1 \\
\hline 14 & 1.1 & 75 & 16.0 & 1 & $98 \pm 9$ & $72 \pm 12$ & 26ป & ND & 0 & 0.97 & 2.1 \\
\hline 13 & 1.1 & 105 & 6.7 & 2 & $95 \pm 11$ & $68 \pm 15$ & 27 ปี & + & 0 & 1.15 & 3.1 \\
\hline 12 & 0.9 & 115 & ND & 2 & $94 \pm 28$ & $67 \pm 10$ & 27 व & + & $1: 40,960$ & 0.76 & 2.9 \\
\hline 11 & 0.8 & 107 & 2.0 & 2 & $100 \pm 11$ & $70 \pm 12$ & 30 ป & ND & 0 & 0.88 & 2.8 \\
\hline 8 & 0.7 & 64 & 0.3 & 2 & $99 \pm 7$ & $65 \pm 14$ & $34 \pi$ & 0 & 0 & 0.94 & 2.7 \\
\hline 7 & 1.5 & 78 & 16.0 & 1 & $108 \pm 16$ & $70 \pm 13$ & 38 ฯ & + & 0 & 1.00 & 2.5 \\
\hline 2 & 1.2 & 93 & 9.9 & 3 & $92 \pm 58$ & $38 \pm 15$ & 54 ป & 0 & 0 & 1.00 & 4.2 \\
\hline Sroup & \multicolumn{11}{|c|}{ Diminished renal function $\left(\mathrm{Cr}>2.0 \mathrm{mg} / 100 \mathrm{ml}\right.$ or $\mathrm{C}_{\mathrm{cr}} \leq 60 \mathrm{ml} / \mathrm{min}$ per $1.73 \mathrm{~m}^{2}$ ) } \\
\hline 41 & 3.3 & 15 & 6.4 & 4 & $43 \pm 3$ & $69 \pm 11$ & -26 & ND & 0 & 0.42 & 7.3 \\
\hline 29 & 5.7 & $<10$ & 7.8 & 4 & $44 \pm 4$ & $39 \pm 7$ & 5 & 0 & 0 & ND & 9.7 \\
\hline 20 & 1.2 & 50 & 6.6 & 4 & $80 \pm 6$ & $67 \pm 12$ & 13 & $* *$ & $1: 80$ & 0.49 & 5.2 \\
\hline 15 & 5.6 & $<10$ & 5.0 & 4 & $75 \pm 17$ & $51 \pm 21$ & 24 & 0 & $1: 640$ & 0.71 & 9.6 \\
\hline 10 & 10.7 & $<10$ & 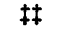 & 4 & $98 \pm 9$ & $67 \pm 12$ & 31 ข & ** & 0 & 0.73 & 14.7 \\
\hline 9 & 1.1 & 50 & 2.0 & 4 & $100 \pm 11$ & $68 \pm 14$ & $32 \pi$ & + & $1: 2,560$ & 1.10 & 5.1 \\
\hline 6 & 5.7 & 8 & 3.7 & 3 & $111 \pm 10$ & $73 \pm 11$ & $38 \pi$ & 0 & 0 & 0.91 & 8.7 \\
\hline 5 & 4.0 & ND & ND & 1 & $89 \pm 48$ & $47 \pm 18$ & 42 ขี & 0 & $1: 5,120$ & 0.55 & 5.0 \\
\hline 4 & 2.0 & 32 & 6.7 & 4 & $95 \pm 24$ & $49 \pm 15$ & $46 \pi$ & $* *$ & $1: 10,240$ & 0.55 & 6.0 \\
\hline 3 & 9.0 & $<10$ & $\sharp$ & 4 & $128 \pm 44$ & $74 \pm 8$ & $54 \pi$ & 0 & 0 & 0.88 & 13.0 \\
\hline 1 & 1.5 & 32 & 11.0 & 4 & $161 \pm 69$ & $47 \pm 16$ & 114 ป & o & 0 & 0.64 & 5.5 \\
\hline
\end{tabular}

ND, not determined.

* See Methods.

$\ddagger$ Net FII-binding globulin = average patient value minus average of control.

\$ Precipitins with heat-aggregated IgG. $0=$ negative, $+=$ positive.

$\| \beta_{1} \mathrm{C} / \beta_{1} \mathrm{~A}$ values in milligrams $/$ milliliter (normal range $=0.7-2.1 \mathrm{mg} / \mathrm{ml}$ ).

II Mean FII-binding globulin concentration in patient sample exceeds mean control by more than $2 \mathrm{SD}$.

** Visible at $48 \mathrm{~h}$ in unstained gels.

\# Urine output $<600 \mathrm{ml} / \mathrm{day}$.

${ }^{125} \mathrm{I}$-patient and ${ }^{182} \mathrm{I}$-normal globulins was filtered through a $0.22-\mu \mathrm{m}$ membrane and incubated at $22^{\circ} \mathrm{C}$ for $2 \mathrm{~h}$ and then at $4^{\circ} \mathrm{C}$ overnight with immunoadsorbents coated either with human FII, fragments of human glomerular basement membranes (GBM), or ovalbumin (OVA) (24). Measurements were performed in triplicate. After incubation, the adsorbents were washed three times in $10 \mathrm{vol}$ of PBS and counted for radioactivity. After correction for the quantities of normal and patient globulins present in the original incubation mixture the quantity of patient globulin less the quantity of ${ }^{121}$ I-normal globulin which remained bound was used as the measure of antibody activity in the patient 
sample. Net antibody activity was calculated according to the formula: (micrograms patient globulin bound/milligrams patient globulin added)-(micrograms control globulin bound/milligrams control globulin added) $=$ net activity (micrograms/milligram). Globulins eluted from the washed adsorbents with $0.1 \mathrm{M}$ phthallate- $\mathrm{HCl}, \mathrm{pH} 3,(18,24)$ were also measured by radioactive counting. To ensure that the ${ }^{131}$ I-labeled control for nonspecific binding had uniform binding characteristics it was adsorbed with FII and human GBM immunoadsorbents before use.

Preparation of immunoadsorbents. FII and OVA immunoadsorbents were prepared as previously described with bentonite clay as the insoluble matrix $(24)$. ( $5 \times$ recrystallized OVA was also obtained from Pentex). GBM was prepared from normal human kidneys obtained less than 6 $\mathrm{h}$ after death. Glomeruli were separated by a modification of the technique of Krakower and Greenspon (25) and sonicated at 20,000 cycles $/ \mathrm{s}$ at $63 \mathrm{~W} / \mathrm{cm}^{2}$ for $60 \mathrm{~s}$ at $4^{\circ} \mathrm{C}$. The sonicate was centrifuged at $1,500 \mathrm{~g}$ for $20 \mathrm{~min}$. The fine particulate material which remained in the supernate after this centrifugation was adsorbed to bentonite particles and the GBM coating was stabilized with 1-ethyl-3-(3-dimethylaminopropyl) carbodiimide- $\mathrm{HCl}(24)$. GBM and other immunoadsorbents were adjusted to a protein concentration of $1 \mathrm{mg} / \mathrm{ml}$ before use in a binding assay.

Miscellaneous techniques. By immunoelectrophoresis using commercially available antisera to human serum proteins (Meloy Laboratories, Inc., Biological Products Division, Springfield, Va.), the FII used in these studies contained IgG with traces of $\operatorname{IgA}$ and $\operatorname{IgM}$. Antiglobulin in serum previously heated to $56^{\circ} \mathrm{C}$ for 30 min was measured by agglutination of latex particles coated with FII and by a double diffusion in $0.7 \%$ agarose against heat-aggregated $\left(63^{\circ} \mathrm{C}, 20\right.$ $\mathrm{min}){ }^{125} \mathrm{I}-\mathrm{IgG}$ at a concentration of $2.8 \mathrm{mg} / \mathrm{ml}(26,27)$. The test for antiglobulin precipitins was performed with unselected sera from 27 of the 41 patients. These sera were also tested against native IgG at the same protein concentration under identical conditions. Sera from two patients with RA and 15 healthy donors were used as controls. Precipitins were visualized directly after diffusion for $48 \mathrm{~h}$ at $22^{\circ} \mathrm{C}$ and by autoradiography after the gels were washed, dried, and incubated with $\mathrm{X}$-ray film for up to 9 days.

C3 $\left(\beta_{1} C / \beta_{1} A\right.$ globulin) was measured by single radial diffusion with a commercially available kit (Meloy Laboratories). The mean and normal range for $\mathrm{C} 3$, determined by testing sera stored for the same length of time and under the same conditions $\left(-70^{\circ} \mathrm{C}\right)$ from seven healthy normal people in these radial diffusion plates, was $1.4 \pm 0.70 \mathrm{mg} / \mathrm{ml}$ (mean $\pm 2 \mathrm{SD}$ ).

Sera and globulin preparations were not heat inactivated before testing except as noted.

\section{RESULTS}

Classification of patient population. Pertinent clinical, histological, and serological data from 41 consecutive patients who underwent renal biopsy are presented in Tables I and II. The patients were a heterogeneous group including 13 patients with definite SLE (28), one with possible amyloidosis (no. 8), and two patients with a strong family history of nephritis (nos. 11 and 13). Of these only no. 11 had acoustic nerve deafness and presence of foam cells in his renal biopsy. One patient, no. 4, displayed typical pulmonary and renal findings of Goodpasture's syndrome; renal biopsies from three other patients showed only linear deposition of immunoglobulin (nos. 5, 7, and 27). None of these had a history of hemoptysis or pulmonary infiltrates. Two patients, nos. 3 and 15, had a clinical course suggestive of rapidly progressive glomerulonephritis. The severity index was significantly different among the three groups shown in Tables I and II (Kruskal-Wallis one-way analysis of variance, chi-square $=28.52 \mathrm{df}-2, \quad P<$ 0.001 ).

Latex test and precipitin tests for antiglobulin activity. None of the sera from the 12 patients in group A reacted in the latex test. Sera from 4 of 18 patients $(22 \%)$ in group B and from 5 of the 11 patients $(45 \%)$ in group $\mathrm{C}$ were positive in this assay. Thus, positive tests for rheumatoid factor were found more frequently in patients with histological evidence of glomerular disease (groups B and C) (chi-square $=4.76, \mathrm{df}=1$, $P<0.05)$ but the titer of the positive sera did not correlate with the severity index (rank correlation test, $P>0.10$ ).

Similarly in 27 patients whose sera were tested for precipitating antibodies to aggregated $\mathrm{IgG}$, none of seven group A patients were reactive whereas five of ten group B and four of ten group C patients' sera precipitated with this reagent. As with the latex fixation test, a positive test was found more frequently in groups $\mathrm{B}$ and $\mathrm{C}$ (chi-square $=4.71, \mathrm{df}=1, P<0.05$ ). The precipitin lines were visible at $48 \mathrm{~h}$ by naked eye in three cases (patients 4, 9, and 20) and in the remainder (six patients) by autoradiography. There was no correlation between a positive test in the latex fixation assay and the presence of precipitins reactive with heat-aggregated IgG. Sera from 2 of 15 normal donors and both patients with rheumatoid arthritis also contained precipitins reactive with aggregated IgG. Only sera from patient 4 precipitated with native $\operatorname{IgG}$ and this reaction was only visible after autoradiography. In all other cases, no precipitin lines were visible even after autoradiography with native IgG.

Studies of kidney biopsies with fluorescein-conjugated human IgG (Table III). Tissue from group $\mathrm{A}$ and group B patients did not react with fluorescein conjugates of native or aggregated IgG. In contrast tissue from eight of nine group $C$ patients reacted with one or both of these conjugates (Fig. 1). Glomeruli in biopsies from four of nine patients in group $C$ selectively fixed heat-aggregated IgG. (nos. 1, 4, 11, and 29) In patient 1 , a few (8/108) of the glomeruli also reacted with the nonaggregated IgG conjugate. In four other group $C$ patients, the glomeruli fixed both native and heat-aggregated IgG (nos. 3, 9, 10, and 20). In both patients 9 and 10, the glomeruli contained immunoglobulin deposits reactive with both anti-IgG and anti-IgM but not with anti-IgA, suggesting that these tissues had no 
TABLE III

Binding of Fluorescein-Labeled Native and Aggregated IgG to Renal Biopsy Tissue Sections. Comparison with Results of Tests for Antiglobulin and Indices of Disease Activity

\begin{tabular}{|c|c|c|c|c|c|c|c|}
\hline \multirow[b]{2}{*}{$\begin{array}{c}\text { Patient } \\
\text { no. }\end{array}$} & \multirow[b]{2}{*}{$\begin{array}{l}\text { Severity } \\
\text { index }\end{array}$} & \multirow[b]{2}{*}{$\begin{array}{c}\text { Latex } \\
\text { fixation } \\
\text { titer }\end{array}$} & \multirow{2}{*}{$\begin{array}{l}\text { Pptn } \\
\text { with } \\
\text { agg } \\
\text { IgG }\end{array}$} & \multirow[b]{2}{*}{$\begin{array}{l}\text { Net FII- } \\
\text { binding } \\
\text { globulin }\end{array}$} & \multicolumn{2}{|c|}{ Binding of fluorescein-IgG } & \multirow[b]{2}{*}{$\begin{array}{l}\text { Ig class of } \\
\text { glomerular } \\
\text { deposits }\end{array}$} \\
\hline & & & & & $\begin{array}{c}\text { Not } \\
\text { aggregated } \\
\text { (control) }\end{array}$ & $\begin{array}{c}\text { Heat } \\
\text { aggregated }\end{array}$ & \\
\hline & & & & $\begin{array}{l}\mu g \text { bound/ } \\
\text { mg added }\end{array}$ & No. glomer & s./total no. & \\
\hline
\end{tabular}

Group A Renal biopsy normal by light microscopy; normal renal function

\begin{tabular}{|c|c|c|c|c|c|c|c|}
\hline 21 & 1.9 & $\mathbf{N}$ & 0 & 12.7 & $0 / 3$ & $0 / 2$ & $\mathrm{G}, \mathrm{M}$ \\
\hline 31 & 2.2 & $\mathrm{~N}$ & 0 & 1.4 & $0 / 2$ & $0 / 2$ & $\mathrm{G}, \mathrm{M}, \mathrm{A}$ \\
\hline up & \multicolumn{7}{|c|}{ Renal biopsy abnormal or proteinuria $>2 \mathrm{~g} / 24 \mathrm{~h}$} \\
\hline 14 & 2.1 & $\mathbf{N}$ & ND & 26.4 & $0 / 7$ & $0 / 3$ & $\mathrm{G}, \mathbf{M}, \mathbf{A}$ \\
\hline 8 & 2.7 & $\mathrm{~N}$ & 0 & 33.5 & $0 / 7$ & $0 / 6$ & $\mathrm{G}, \mathbf{M}$ \\
\hline 25 & 2.9 & $\mathbf{N}$ & ND & 7.0 & $0 / 5$ & $0 / 4$ & $\mathrm{G}, \mathbf{M}$ \\
\hline 12 & 2.9 & $1: 40,960$ & + & 27.3 & $0 / 3$ & $0 / 2$ & $\mathbf{M}$ \\
\hline 22 & 2.9 & ND & ND & 71.8 & $0 / 6$ & $0 / 7$ & $\mathrm{G}, \mathrm{M}$ \\
\hline 17 & 4.0 & $1: 10,240$ & + & 17.6 & $0 / 21$ & $0 / 10$ & $\mathrm{G}$ \\
\hline 2 & 4.2 & $\mathrm{~N}$ & 0 & 53.6 & $0 / 6$ & $0 / 3$ & G \\
\hline
\end{tabular}

Group C Diminished renal function $\left(\mathrm{Cr}>2.0 \mathrm{mg} / 100 \mathrm{ml}\right.$ or $\mathrm{C}_{\mathrm{Cr}} \leq 60 \mathrm{ml} / \mathrm{min}$ per $\left.1.73 \mathrm{~m}^{2}\right)$

\begin{tabular}{rccccccl}
9 & 5.1 & $1: 2,560$ & + & 31.8 & $21 / 21$ & $24 / 24^{*}$ & G, M \\
20 & 5.2 & $1: 80$ & + & 12.8 & $1 / 1$ & $1 / 1$ & G, M, A \\
1 & 5.5 & $\mathrm{~N}$ & 0 & 114.1 & $8 / 108$ & $74 / 92$ & G, M \\
4 & 6.0 & $1: 10,240$ & + & 46.2 & $0 / 2$ & $2 / 2$ & G, M, A \\
41 & 7.3 & $\mathrm{~N}$ & $\mathrm{ND}$ & -25.9 & $0 / 3$ & $3 / 3$ & $\mathrm{G}, \mathrm{M}, \mathrm{A}$ \\
15 & 9.6 & $1: 640$ & 0 & 24.4 & $0 / 46$ & $0 / 47 \ddagger$ & $\mathrm{M}$ \\
29 & 9.7 & $\mathrm{~N}$ & 0 & 4.6 & $0 / 22$ & $5 / 10$ & $\mathrm{G}, \mathrm{M}$ \\
3 & 13.0 & $\mathrm{~N}$ & 0 & 53.5 & $2 / 21$ & $2 / 21 \ddagger$ & $\mathrm{G}, \mathrm{M}, \mathrm{A}$ \\
10 & 14.7 & $\mathrm{~N}$ & + & 31.2 & $3 / 48$ & $8 / 44 \ddagger$ & $\mathrm{G}, \mathrm{M}$ \\
\hline
\end{tabular}

$\mathrm{N}$, negative at 1:40 dilution; ND, not done; Pptn with agg IgG = precipitin with aggregated IgG; $+=$ positive $; 0=$ negative.

* Fluorescence of glomeruli treated with the aggregated IgG was notably greater than in the sections treated with the control.

$\ddagger$ The majority of the glomeruli were obsolescent.

unusual non-specific affinity for fluorescein-conjugated proteins. In one case (patient 1 ), the availability of a surgical biopsy provided tissue for additional studies. In this case, heating the tissue to $56^{\circ} \mathrm{C}$ for $30 \mathrm{~min}$ did not abolish fluorescence with the aggregated IgG conjugates. Moreover adsorption of the aggregated IgG conjugate with insolubilized human $\mathrm{IgG}$ or with human liver powder did not alter the immunofluorescence. However, the reaction was blocked when tissue sections were pretreated with unconjugated aggregated IgG or antibody specific for IgM before incubation with fluorescein-labeled aggregated IgG. Prior incubation with unconjugated native $\operatorname{IgG}$, anti-IgG, or anti-IgA did not block the reaction.

Lack of correlation between antiglobulins in renal tissue and serum. Relation to serum C3 levels. Sera from three of the four group $\mathrm{C}$ patients whose biopsies selectively fixed aggregated $\operatorname{IgG}$ were unreactive in the latex test. On the other hand, serum from the one group C patient whose biopsy did not react with fluoresceinconjugated human IgG had a latex titer of $1: 640$. Similarly, in two group B patients (nos. 12 and 17) whose sera had very high latex fixation titers, the kidney tissue did not bind aggregated or native IgG. Thus, there was no correlation between serological reactivity in the latex test and the presence of antiglobulin activity in the glomeruli. In three of the four patients whose glomeruli reacted selectively with aggregated IgG, serum C3 levels were significantly lower than in other group $\mathrm{C}$ patients whose kidney tissue did not react or reacted with both native and aggregated IgG (compare Tables I and III).

Measuring the binding of patient globulins to insolubilized FII. Binding of ${ }^{150} \mathrm{I}$-patient globulin to immunoadsorbents coated with FII was proportional over a sixfold range to the quantity of iodinated protein added 

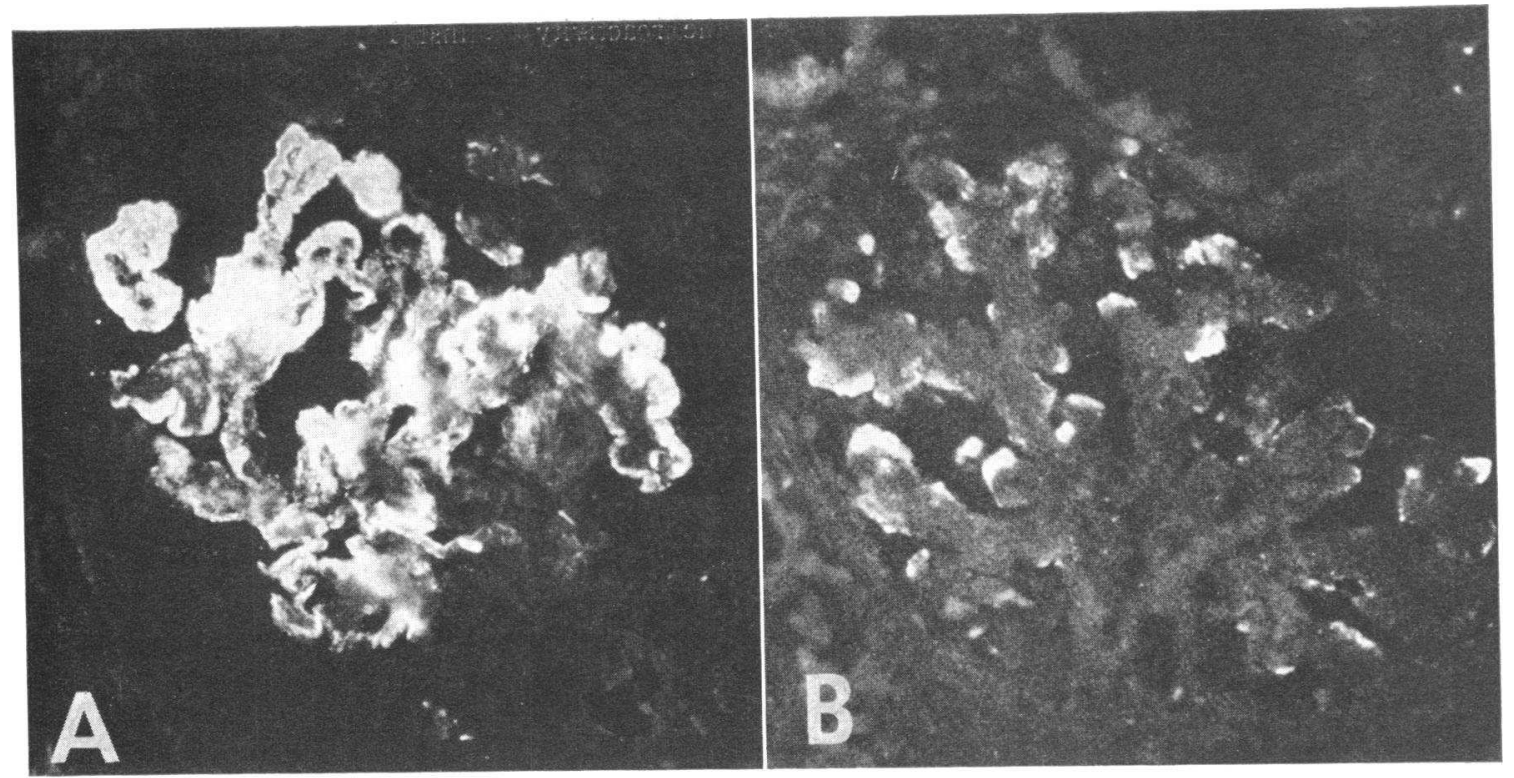

FIGURE 1 Examples of immunofluorescence in glomeruli which bound fluorescein-labeled aggregated IgG. (A) $3+$ reaction; (B) $1+$ reaction. $264 \times$.

(Fig. 2). Binding of the control varied over a relatively narrow range among all samples tested $(60.1 \pm 12.9$ $\mu \mathrm{g} / \mathrm{mg}$, mean $\pm \mathrm{SD}$ ). In 14 cases the bound quantity of patient globulin exceeded the binding of its own control by 2 SD or more (Table II). Approximately $20 \%$ of the globulins which bound to the adsorbent could be eluted at $\mathrm{pH} 3$. The quantity eluted was proportional to that which bound initially, and there was little overlap in the quantities of eluate obtained with the patient and the control samples (Fig. 3). Measurement of the net



Figure 2 Binding of ${ }^{125}$ I-labeled globulins from seven patients to FII immunoadsorbents. ${ }^{125} \mathrm{I}$-globulins were mixed with an equal quantity of ${ }^{131}$ I-labeled control and tested at three different concentrations with $1 \mathrm{mg}$ adsorbent-bound antigen. Binding of globulins was proportional to the quantity added to the incubation mixture. The shaded area shows the variance $( \pm 2 \mathrm{SD})$ in the quantity of ${ }^{181}$ I-control globulin bound over the range of the experiment.
FII-binding globulin in most cases varied by $\pm 15 \%$ (SD).

Correlations observed between FII binding and the severity of renal disease. High net quantities of FIIbinding globulin were generally found in sera from pa-

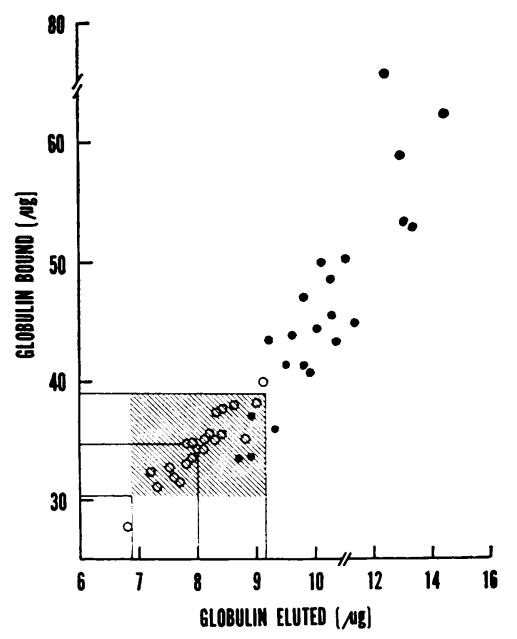

FIGURE 3 Elution of bound globulin from insolubilized FII. Patient samples were mixed with equal quantities of control globulins and incubated with FII immunoadsorbents. After washing, the globulins which could be eluted at $\mathrm{pH} 3$ with $0.1 \mathrm{M}$ phthalate- $\mathrm{HCl}$ were measured. The quantity eluted (abscissa) is shown as a function of the quantity of globulin which bound to the adsorbent before elution (ordinate). Closed circles show results for individual patient samples; open circles, the results for the controls. The shaded area indicates the variation ( $\pm 2 \mathrm{SD}$ ) in the binding and elution values for the control samples. 


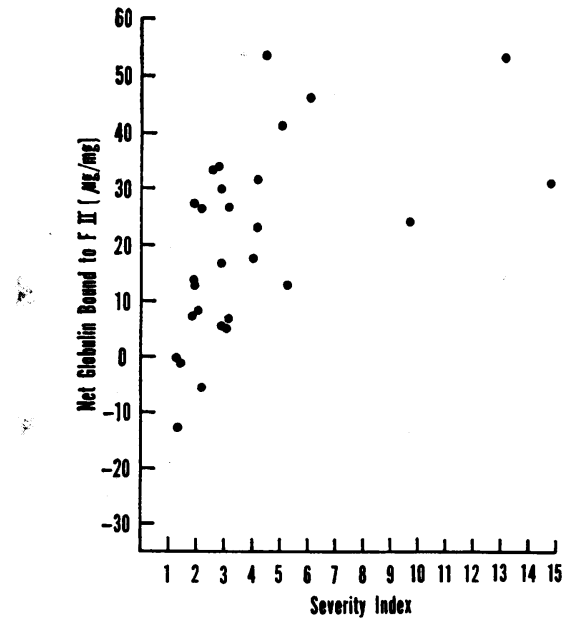

FIGURE 4 Comparison of the net FII binding values with the severity index in 28 patients who did not have SLE. Each point represents the mean of at least triplicate measurements for one or more serum samples for each patient The severity index is a numerical value which takes into account both renal clearance and histological abnormalities in the renal biopsy. The mean value for the normal controls is shown as zero on the ordinate.

tients in groups B and C. Overall the severity indices correlated with the level of FII-binding globulin ( $\mathrm{Ta}$ ble I) (Spearman rank correlation test, $r=0.465, n=$ $41, P<0.01$; Kruskal-Wallis one-way analysis of variance, $\mathrm{H}=15.56$ equivalent to chi-square for $\mathrm{df}=2$ of $>14, P<0.001)$.

In 28 patients who did not have SLE (Fig. 4), the net quantity of this serum factor correlated particularly well with the severity index $(r=0.629, P<0.001$, Spearman rank test, $n=28$ ). On the other hand in 13 patients with SLE there was no correlation between the level of FII-binding globulin and the severity indices $(r=0.325, P>0.10$, Spearman rank correlation test, $n=13$ ). Only two SLE patients (nos. 1 and 6 ) had very high levels of FII-binding globulin.

Specificity of the immunoadsorbent assay. Net binding of patient globulins to GBM was proportional to their binding to FII. But the binding of both patients and control samples to GBM was greater than to FII, reflecting the greater capacity of GBM immunoadsorbents to bind human globulin nonspecifically (Table IV). Adsorption with sufficient FII to remove reactivity to that antigen also abolished reactivity to GBM. 21 globulin samples from the sera of eight patients and two normal donors were also tested against immunoadsorbents coated with OVA. The OVA immunoadsorbents had an even greater capacity to bind human globulin nonspecifically (Table IV). Adsorption of patient samples which contained high levels of net FII binding activity with OVA also removed most of the reactivity against FII. Thus, the experience with these immunoadsorbents did not indicate that the FII binding measurements were a specific test for antiglobulin activity.

Relationship of disease activity to serum C3 levels and the intensity of the immunofluorescence with antihuman immunoglobulin reagents. Neither the severity index nor the level of FII-binding globulins correlated with the serum level of C3. Moreover, age, sex, duration of disease, and intensity of immunofluorescence with anti-IgG or anti-IgM did not correlate with the severity index. Notably deposits of IgG and/or IgM were often found in glomeruli which showed little other histologic evidence of disease.

\section{DISCUSSION}

We have pursued four lines of investigation to evaluate whether antiglobulins may be associated with the development of progressive renal disease in patients with glomerulonephritis: (a) immunofluorescence studies of renal biopsy tissue, $(b)$ reactivity of sera in the latex fixation test, (c) measurement of serum precipitins reactive with aggregated $\mathrm{IgG}$, and $(d)$ measurement of the total serum globulins which will bind to insolubilized human IgG and other antigens.

Tissue studies with fluorescein conjugates of native and aggregated human IgG discriminated most sharply between patients with advanced glomerular lesions and those with little or no histological evidence of glomerular injury. None of the tissues from patients in groups $A$ and $B$ reacted with these conjugated proteins. On the other hand, tissue from eight or nine group $C$ patients fixed one or both reagents. In four cases, the glomerular deposits selectively fixed heat-aggregated IgG; tissues from the other four reacted with both native and denatured immunoglobulin. In two of the latter cases, it was unlikely that the tissue had any unusual affinity for fluoresceinated proteins. It is conceivable that the native IgG contained antibodies reactive with antigens in the glomeruli of these four group $\mathrm{C}$ patients. If so, it is hard to imagine why it reacted selectively with the tissues from the most

\section{TABLE IV}

Average Binding of Pooled Normal Human Globulins to Immunoadsorbents Coated with FII, GBM Fragments, or Ovalbumin

\begin{tabular}{cc}
\hline Immunoadsorbent & Quantity bound \\
\hline & $\mu g / m g$ added $( \pm S D)$ \\
FII & $60.1 \pm 12.9$ \\
GBM & $117 \pm 10.5$ \\
OVA & $283.1 \pm 7.2$ \\
\hline
\end{tabular}


severely affected patients. Antiglobulins can react with antigens of native $\operatorname{IgG~(29)~and~this~also~may~be~the~}$ basis for these reactions. Biopsies from a second series of patients are being studied for the ability to fix fluorescein-labeled proteolytic fragments of IgG to evaluate the specificity of this reaction.

In one case, heating the tissue sections did not abolish fixation of fluorescein-labeled heat-aggregated IgG whereas this property could be blocked with unconjugated anti-IgM, suggesting that $\operatorname{IgM}$ antiglobulins rather than $\mathrm{Clq}$ were responsible for the tissue localization of aggregated $\mathrm{IgG}$ in this patient. Since the tissue sections from other patients were not heated before testing with aggregated $\operatorname{IgG}$ (21), we cannot exclude the possibility that $\mathrm{C} 1 \mathrm{q}$ rather than antibodies specific for native or heat-aggregated IgG was responsible, in some, for the tissue-fixed antiglobulin activity (30).

Antiglobulins were also detected more frequently by the latex fixation and precipitin tests in sera from patients with groups $B$ and $C$ renal disease. The serum precipitins and the latex reactive factors were: heat stabile and therefore unlikely to represent $\mathrm{Clq}$ activity. However, patients whose sera contained antiglobulin activity did not necessarily have antiglobulin deposits in their renal tissues. The poor correlation between the histological and serological observations suggested that the latex and precipitin tests were not detecting all antiglobulins in these patients' sera (31). Therefore it was desirable to develop a more comprehensive test for antiglobulin activity. Standard radioimmunoassay procedures were precluded by the intrinsic properties of IgG as antigen, viz., its insolubility under the conditions required for the Farr assay and its reactivity with antiimmunoglobulin isotype sera used to separate antigen-antibody complexes from free antigen $(32,33)$. While human Fab and Fc antigenic fragments have been used in a modified Farr assay for antiglobulin (34), this approach precludes the measurement of antibodies reactive with antigens which reflect the quaternary structural characteristics of the molecule (35). Moreover, antiglobulin factors commonly react with antigenic sites which are exposed only in IgG molecules which have been deformed as a result of antigenantibody reactions or denaturation (29). With these considerations in mind the immunoadsorbent assay used in these studies was adopted.

Although this test produced a higher frequency of positive reactions than the latex fixation test and correlated well with the severity index (except in patients with SLE) it did not provide a specific measure of antiglobulin antibody and its results did not correlate with the latex fixation or antiglobulin precipitin assays.
The high nonspecific binding of normal globulins by OVA and GBM immunoadsorbents which were used as specificity controls in this assay ensured that these also became de facto immunoadsorbents for antiglobulin. As a result it is probable that this assay appeared to be more nonspecific than it actually was. Unfortunately, an average of only $20 \%$ of the globulins which bound to any of the three immunoadsorbents could be eluted with acidic buffers. Therefore, adequate characterization of the FII-binding globulins or those which reacted with OVA and GBM adsorbents was not possible.

Attempts to eluate antiglobulins from kidneys have also met with a low incidence of success $(36,37)$, except in some patients with SLE and cryoglobinemia $(13-15,38)$. In these, the observations suggest that cryoantiglobulins are deposited in the kidney as part of an immune complex. We did not examine the sera of our patients for cryoglobulin activity. Moreover, if cold-insoluble immunoglobulins were present, it is quite likely that they would have been discarded when the sera were processed for various serologic measurements. Thus the lack of a correlation between the serologic tests for antiglobulin activity and the severity of disease in SLE patients in this study could reflect a failure to specifically investigate sera for the presence of cryoantiglobulins. Nevertheless, the immunofluorescence data suggest that antiglobulins may be incorporated in glomerular immunoglobulin deposits in SLE patients. Four of the eight patients whose kidney tissue reacted with aggregated or native IgG had SLE or a related syndrome.

Although these data suggest that antiglobulins are found more frequently in the tissues and sera of patients with relatively severe glomerular injury, they do not necessarily indicate that antiglobulins influence the inflammatory response within the glomeruli. In experimental animals, human antiglobulins are not directly nephrotoxic (16). Moreover, they are not thought to be directly nephrotoxic in man, either. Patients who have RA and high levels of circulating rheumatoid factors for months or years generally do not develop glomerulonephritis. Indeed, it has been suggested that rheumatoid factors may actually protect kidneys under certain circumstances from deposition of immune complexes $(5,39)$. Most likely this would occur in circumstances where the antiglobulins increased the size of immune complexes above that which readily deposit in glomerular capillaries. In vitro evidence can also be cited to suggest that, under certain conditions, antiglobulins can inhibit complement-mediated tissue injury $(40,41)$. On the other hand, McCormick, Day, Morris, and Hill have presented data which suggest that antiglobulin-rich serum fractions can augment the tissue injury caused by nephrotoxic antisera (16). If 
the correlation between disease severity and presence of antiglobulins in sera or glomeruli in these patients indeed reflects a pathogenic role for antiglobulins in human glomerulonephritis, one can envision at least two mechanisms by which they could augment renal glomerular injury: (a) antiglobulins could combine with antigen-antibody complexes while these were still in the circulation and facilitate their deposition in the kidney and ( $b$ ) they could bind to immune complexes or GBM-reactive antibodies after these had impinged on the glomerular membranes. In either case, one would expect an apparent increase in the quantity of immunoglobulin deposited in the glomeruli and/or also an increase in the quantity of complement activated at that site. In experimental nephritis, it is recognized that the extent of glomerular injury is closely related to the quantity of immunoglobulin and antigen deposited in the renal glomeruli $(42,43)$. In this patient population, however, there was no correlation between histologic evidence of glomerular injury or presence of glomerular antiglobulin deposits and the intensity of the immunofluorescence seen with anti-IgG, anti IgA, or anti-IgM conjugates. In fact, intensely fluorescent deposits were often found with these reagents in tissue from patients (group A) who had little other histologic evidence of glomerulonephritis. Thus, these observations do not support the notion that antiglobulins increase glomerular immunoglobulin deposition, and it is not presently clear whether the antiglobulin response in patients with severe nephritis represents an uninvolved witness or a contributing influence to the intense renal inflammation which has occurred in such patients.

\section{ACKNOWLEDGMENTS}

We gratefully acknowledge the assistance of Dr. M. Sidney Anderson of the Department of Pathology, who reviewed all of the renal biopsy sections, and the technical assistance of Ruth Rickaway, Connie Schimbor, Sandra Farrow, and Abraham Solomon.

This work was supported by grants HL 17269 , HL 05435 , RR 00350, AM 015494, and AM 17555 from the National Institutes of Health, the American Heart Association, Texas Affiliate, and the Veterans Administration Hospital, Houston, Tex.

\section{REFERENCES}

1. McCluskey, R. T., and D. S. Baldwin. 1963. Natural history of acute glomerulonephritis. Am. J. Med. 35: 213-230.

2. Mandalenakis, N., N. Mendoza, C. L. Pirani, and V. E. Pollak. 1971. Lobular glomerulonephritis and membranoproliferative glomerulonephritis. A clinical and pathologic study based on renal biopsies. Medicine (Baltimore ). 50: 319-355.

3. Lewy, J. E., L. Salinas-Madrigal, P. B. Herdson, C. L. Pirani, and J. Metcoff. 1971. Clinico-pathologic correlations in acute poststreptococcal glomerulonephritis. Medicine (Baltimore). 50: 453-501.
4. Unanue, E. R., and F. J. Dixon. 1967. Experimental glomerulonephritis: immunological events and pathogenetic mechanisms. Adv. Immunol. 6: 1-90.

5. Germuth, R., F. G., Jr., and E. Rodriguez. 1973. Immunopathology of the Renal Glomerulus: Immune Complex Deposit and Anti-Basement Membrane Disease. Little, Brown and Company, Boston. 57-180.

6. Cochrane, C. G., and D. Hawkins. 1968. Studies on circulating immune complexes. III. Factors governing the ability of circulating complexes to localize in blood vessels. J. Exp. Med. 127: 137-154 + 3 plates.

7. Kushner, D. S., S. H. Armstrong, Jr., A. Dubin, P. B. Szanto, A. Markowitz, B. P. Maduros, J. M. Levine, G. L. River, T. N. Gynn, and J. P. Pendras. 1961. Acute glomerulonephritis in the adult. Longitudinal, clinical, functional and morphologic studies of rates of healing and progression to chronicity. Medicine (Baltimore). 40: 203-240.

8. Bacani, R. A., F. Velasquez, A. Kanter, C. L. Pirani, and V. E. Pollak. 1968. Rapidly progressive (nonstreptococcal) glomerulonephritis. Ann. Intern. Med. 69: 463485.

9. Restifo, R. A., A. J. Lussier, A. J. Rawson, J. H. Rockey, and J. L. Hollander. 1965. Studies on the pathogenesis of rheumatoid joint inflammation. III. The experimental production of arthritis by the intraarticular injection of purified 7S gamma globulin. Ann. Intern. Med. 62: 285-291.

10. Winchester, R. J., V. Agnello, and H. G. Kunkel. 1969. The joint-fluid $\gamma$ G-globulin complexes and their relationship to intraarticular complement diminution. Ann. N. Y. Acad. Sci. 168: 195-203.

11. Munthe, E. 1970. Relationship between IgG complexes and anti-IgG antibodies in rheumatoid arthritis. Acta Rheumatol. Scand. 16: 240-256.

12. Zvaifler, N. J. 1970. Further speculation on the pathogenesis of joint inflammation in rheumatoid arthritis. Arthritis Rheum. 13: 895-901.

13. Meltzer, M., E. C. Franklin, K. Elias, R. T. McCluskey, and N. Cooper. 1966. Cryoglobulinemia-a clinical and laboratory study. II. Cryoglobulins with rheumatoid factor activity. Am. J. Med. 40: 837-856.

14. Golde, D., and W. Epstein. 1968. Mixed cryoglobulins and glomerulonephritis. Ann. Intern. Med. 69: 12211227.

15. Hanauer, L. B., and C. L. Christian. 1967. Studies of cryoproteins in systemic lupus erythematosus. J. Clin. Invest. 46: 400-408.

16. McCormick, J. N., J. Day, C. J. Morris, and A. G. S. Hill. 1969. The potentiating effect of rheumatoid arthritis serum in the immediate phase of nephrotoxic nephritis. Clin. Exp. Immunol. 4: 17-28.

17. Siegel, S. 1956. Non-parametric Statistics for the Behavioral Sciences. McGraw-Hill Book Company, New York.

18. Reisberg, M. A., R. D. Rossen, and W. T. Butler. 1970. A method for preparing specific fluorescein-conjugated antibody reagents using bentonite immunoadsorbent reagents. J. Immunol. 105: 1151-1161.

19. Rossen, R. D., W. T. Butler, M. A. Reisberg, D. K Brooks, R. D. Leachman, J. D. Milam, K. K. Mittal, J. R. Montgomery, J. J. Nora, and D. G. Rochelle. 1971. Immunofluorescent localization of human immunoglobulin in tissues from cardiac allograft recipients. $J$. Immunol. 106: 171-180. 
20. Mellors, R. C., R. Heimer, J. Corcos, and L. Korngold. 1959. Cellular origin of rheumatoid factor. J. Exp. Med. 110: $875-886+5$ plates.

21. Mellors, R. C., A. Nowoslawski, L. Korngold, and B. L. Sengson. 1961. Rheumatoid factor and the pathogenesis of rheumatoid arthritis. J. Exp. Med. 113: 475-483 +7 plates.

22. Fahey, J. L., P. F. McCoy, and M. Goulian. 1958. Chromatography of serum proteins in normal and pathologic sera: the distribution of protein-bound carbohydrate and cholesterol, siderophilin, thyroxin-binding protein, $\mathrm{B}_{12}$-binding protein, alkaline and acid phosphatases, radio-iodinated albumin and myeloma proteins. J. Clin. Invest. $37: 272-284$.

23. Helmkamp, R. W., R. L. Goodland, W. F. Bale, J. L. Sparr, and L. E. Mutschler. 1960. High specific activity iodination or $\gamma$-globulin with iodine- 131 monochloride. Cancer Res. 20: 1495-1500.

24. Carpenter, R. R., and M. A. Reisberg. 1968. Carbodiimide-induced bentonite-antigen complexes: readily prepared immunoadsorbents. J. Immunol. 100: 873-879.

25. Krakower, C. A., and S. A. Greenspon. 1951. Localization of the nephrotoxic antigen within the isolated renal glomerulus. Arch. Pathol. 51: 629-639.

26. Singer, J. M., and G. M. Plotz. 1956. The latex fixation test. I. Application to the serologic diagnosis of rheumatoid arthritis. Am. J. Med. 21: 888-892.

27. Epstein, W., A. Johnson, and C. Ragan. 1956. Observations of a precipitin reaction between serum of patients with rheumatoid arthritis and a preparation (Cohn Fraction II) of human gamma globulin. Proc. Soc. Exp. Biol. Med. 91 : 235-237.

28. Cohen, A. S., and J. J. Canoso. 1972. Criteria for the classification of systemic lupus erythematosus. Status 1972. Arthritis Rheum. 15: 540-543.

29. Normansell, D. E. 1971. Anti- $\gamma$-globulins in rheumatoid arthritis sera. II. The reactivity of anti- $\gamma$-globulin rheumatoid factors with altered $\gamma$-globulin. Immunochemistry. 8: 593-602.

30. Agnello, V., R. J. Winchester, and H. G. Kunkel. 1970 Precipitin reactions of the $\mathrm{Clq}$ component of complement with aggregated $\gamma$-globulin and immune complexes in gel diffusion. Immunology. 19: 909-919.

31. Waller, M. 1969. Methods of measurement of rheumatoid factor. Ann. N. Y. Acad. Sci. 168: 5-20.
32. Farr, R. S. 1958. A quantitative immunochemical measure of the primary interaction between I*BSA and antibody. J. Infect. Dis. 103: 239-262.

33. Hunter, W. M. 1973. Radioimmunoassay. In Handbook of Experimental Immunology. D. M. Weir, editors. Blackwell Scientific Publications Ltd., Oxford. 2nd edition. 17.1-17.36.

34. Cerottini, J-C. 1968. An antigen-binding capacity test for human immunoglobulin G (IgG) fragments. J. Immunol. 101 : 433-438.

35. Steinberg, A. G. 1964. Population, immunogenetic, and biochemical studies on the $\mathrm{Gm}(\mathrm{b})$ factors of human gamma-globulin. Cold Spring Harbor Symp. Quant. Biol. 29 : 449-454.

36. Koffler, D., P. H. Schur, and H. G. Kunkel. 1967. Immunologic studies concerning the nephritis of systemic lupus erythematosus. J. Exp. Med. 126: $607-624+4$ plates.

37. Koffler, D. V. Agnello, R. I. Carr, and H. G. Kunkel. 1969. Variable patterns of immunoglobulin and complement deposition in the kidneys of patients with systemic lupus erythematosus. Am. J. Pathol. 56: 305-316.

38. Agnello, V., D. Koffler, J. W. Eisenberg, R. J. Winchester, and H. G. Kunkel. 1971. C1q precipitins in the sera of patients with systemic lupus erythematosus and other hypocomplementemic states: characterization of high and low molecular weight types. J. Exp. Med. 134 : 228s-241s.

39. Davis, J. S., IV. 1966. A hypothetical common mechanism in systemic lupus erythematosus and rheumatoid arthritis. Arthritis Rheum. 9: 631-639.

40. Messner, R. P., T. Ladal, P. G. Quie, and R. C. Williams, Jr. 1968. Serum opsonin, bacteria, and polymorphonuclear leukocyte interactions in subacute bacterial endocarditis. Anti- $\gamma$-globulin factors and their interaction with specific opsonins. J. Clin. Invest. 47: 11091120.

41. McDuffie, F. C., and H. W. Brumfield. 1972. Effect of rheumatoid factor on complement-mediated phagocytosis. J. Clin. Invest. 51: 3007-3014.

42. Wilson, C. B., and F. J. Dixon. 1970. Antigen quantitation in experimental immune complex glomerulonephritis. J. Immunol. 105 : 279-290.

43. Wilson, C. B., and F. J. Dixon. 1971. Quantitation of acute and chronic serum sickness in the rabbit. $J$. Exp. Med. $134: 7 \mathrm{~s}-18 \mathrm{~s}$. 